\title{
REFLECTIVE STYLE AND SPEECH PRODUCTION DURING ACADEMIC TASK SOLVING IN UNIVERSITY STUDENTS
}

\author{
Olena Savchenko \\ savchenko.elena.v@gmail.com \\ Vadym Hetman National Economic University of Kyiv, Ukraine \\ ORCID: 0000-0002-7069-7419 \\ Heorhii Kalmykov \\ ORCID: 0000-0002-1378-5236 \\ Donbass State Pedagogical University, Ukraine \\ Liudmyla Malimon \\ ORCID: 0000-0002-2964-6580 \\ malimon.ludmila@eenu.edu.ua \\ Lesya Ukrainka Eastern European National University, Ukraine
}

Received December 19, 2019; Revised March 12, 2020; Accepted April 6, 2020

\begin{abstract}
The aim of the article is to examine the relationship between students' reflective information processing style and speech production during academic tasks solving. The study applies Index of Learning Styles Questionnaire (Felder \& Solomon, 2001) to examine four pairs of learning styles, notably active - reflective, sensing - intuitive, visual - verbal and sequential global. The study applies functional analysis suggested by Naydonov (2008). The students were asked to solve the academic tasks aligned with their knowledge of the academic module. The study applies analysis of fourteen categories according to the following two criteria, notably considering the content/meaning of students' responses and type of solution. The findings indicate that students with a high level of reflective and verbal style less frequently apply category text (34.55 \pm 12.39$)$, comparatively with students with a low level of reflective тa verbal style (65.94 \pm 4.13$)$. Students with a high level of reflective and verbal style more frequently apply category tools $(6.61 \pm 1.96)$ and less frequently category intentions $(1.69 \pm 1.78)$ comparatively with students with a low level of reflective and verbal style (1.06 \pm .78 and $2.30 \pm .71$, respectively). Category models are more frequent in students with a medium level of reflective style (3.61 \pm .99$)$, comparatively with students with a high (2.05 \pm 2.76$)$ and a low (2.69 \pm 1.01$)$ level. Therefore, speech production in categories of models and tools evaluates the best solutions in the academic setting, providing an efficient academic task solving.
\end{abstract} analysis.

Keywords: reflection, reflectivity, reflective style, speech, content and meaning-oriented

Савченко Олена, Калмиков Георгій, Малімон Людмила. Рефлексивний стиль як каталізатор мовленнєвої продукції студентів у процесі розв'язання навчальних задач

Метою дослідження є вивчення взаємозв'язку між рефлексивним стилем обробки інформації та мовленнєвою продукцією студентів у дискурсі, який формується під час розв'язування ними навчальних задач. У дослідженні використаний «Опитувальник стилів навчання» (Felder \& Solomon, 2001) для вивчення чотирьох пар стильових властивостей, а

(C) Savchenko, Olena; Kalmykov, Heorhii; Malimon, Liudmyla, 2020. This is an Open Access article distributed under the terms and conditions of the Creative Commons Attribution 4.0 International Licence (http://creativecommons.org/licenses/by/4.0).

East European Journal of Psycholinguistics, 7(1), 146-155. https://doi.org/10.29038/eejpl.2020.7.1.sav 
саме: активний - рефлексивний, чуттєвий - інтуїтивний, візуальний - вербальний, послідовний - глобальний. У дослідженні застосовувався функціональний аналіз, запропонований М. Найдьоновим (2008). Студентам було запропоновано розв'язати навчальні завдання з певного навчального модуля. У дослідженні застосовувався аналіз за чотирнадцятьма категоріями, які відображали два критерії, зокрема: урахування змісту/смислу відповідей та типу рішення студентів. Отримані результати свідчать, що студенти 3 високим рівнем рефлексивного і вербального стилів рідше використовують категорію текст $(34.55 \pm 12.39)$ у порівнянні зі студентами з низьким рівнем рефлексивного i вербального стилів (65.94 \pm 4.13$)$. Студенти 3 високим рівнем рефлексивного та вербального стилів частіше використовують категорію засіб $(6.61 \pm 1.96)$ та значно рідше категорію намір (1.69 1.78$)$, ніж студенти з низьким рівнем рефлексивного та вербального стилів (відповідно, $1.06 \pm .78$ та 2.30土.71). Категорія модель частіше зустрічається у мовленнєвій продукції студентів з середнім рівнем рефлексивного стилю у порівнянні зі студентами 3 високим (2.05 \pm 2.76$)$ та низьким рівнем $(2.69 \pm 1.01)$. Отже, застосування категорій модель та засіб забезпечує прийняття більш ефективних рішень у процесі навчання, більш успішне розв'язання навчальних завдань.

Ключові слова: рефлексія, рефлексивність, рефлексивний стиль, мовлення, змістовосмисловий аналіз, психосемантичні засоби.

\section{Introduction}

Reflection has a pivotal role for cognitive processes and personal development. Several attempts have been made to define reflection as mental processes. Reflection is defined as an important factor of the individual efficiency. Reflection performs different functions having a strong impact on the outcomes of the individual activity. Moreover, reflection has different shades of meaning aligned with various spheres of individual activity. In particular, reflection as a feature has an impact on development of self-conception; reflection as a process has an effect on critical evaluation of reality and analysis of requirements and possibilities of the situation. Reflection as a mental state is aligned with cognitive processes, and regulates cognitive processing of information. Reflection as a mechanism provides reflection and regulation of individual intentions towards self-development. Reflection as an ability related to individual readiness to perceive, analyze and regulate mental processes. Finally, reflection is considered as an important predictor of individual development and self-realization.

The main difficulties aligned with theoretical approached to reflection are various definition even within one suggested framework. In particular, there are different definitions of reflection as a feature, notably systemic ability (Karpov, 2004); predictor of individual self-determination and self-development (Sharov, 2006), predictor of thinking (Semenov \& Stepanov, 1989), form of cognitive process (Schedrovitskii, 2003), way of human existence (Rubinstein, 2003). The existing body of research on reflection suggests that reflection is the characteristics of individual style, aligned with making decision and behavioral strategies of the life problem solving.

Style is a stable individual feature, which predicts the characteristics of the individual activity. Kholodnaya (2004) suggests several types of style features, which characterize the individual intelligence, notably information processing, 
intellectual styles, and epistemological styles. The reflective style is represented at the four levels: as information processing style (Felder \& Solomon, 2001), decision making in the situation of ambiguity (Kagan, 1965) style of problem solving (Savchenko, 2015), styles of existence (Rubinstein, 2003; Starovoitenko, 2007).

The attitude to the information processing before the information could be applied is defined as reflective style of information. Felder and Solomon (2001) suggest four pairs of style feature, notably active-reflective, sensing-intuitive, visual-verbal, and sequential-global. Kagan (1965) points out that reflectivity is the attitude to the correct decision making in a multiple choice situation. Moreover, this style is slow and contrasting the impulsive style. Savchenko (2015) suggests four styles for problem solving, particularly active, avoiding, constructive-reflective, and deconstructive-reflective. Extensive research has shown that reflection has an ambivalent nature, and might have both a positive and negative impact on the individual efficiency (Savchenko, 2016). Rubinstein (2003) points out two ways of personality's attitude towards the world, notably trivial and reflective. Recently investigators have examined the effects of individual awareness on individual existence, and furthermore, defined four types of personality, in particular personality in everyday life, active personality, reflective personality, and creative personality with valuable ideas. (Starovoitenko, 2007). Currently, there are no data on effect of reflective information processing style on individual speech and academic task solving in students.

The aim of the study is to examine the relationship between reflective information processing style and academic task solving.

Evidence of recent research shows that there is a strong association between reflection and language abilities and skills (Vygranska, 2019). Moreover, reflection is views as a robust predictor of language competence. Bosa (2017) argues that reflection as a component of language competence; Kulyk points out that reflective abilities are predictors of speech development; Zalevskaya (2015) considers reflection in the context of meta-speech. The objective of the empirical study in the current paper is to examine the relationship between reflective style and speech production in students.

\section{Methods}

The study applies "Index of learning styles questionnaire" (Felder \& Solomon, 2001) to examine four pairs of style feature, notably active-reflective, sensingintuitive, visual-verbal ta sequential-global. Students' speech was also recorded in the study. Students were commenting their hypothesizing and making decisions during academic task solving. The study applies functional analysis suggested by Naydonov (2008). The students were asked to solve the academic tasks aligned with their knowledge of the academic module. Students were solving eight close tasks (participants knew that there is a predetermined solution in the task) and one open task (participants knew that there is no predetermined solution) at different complexity level. The close tasks also include multiple choice tasks. Students were asked to express their thoughts, emotions and intentions during the academic task 
solving. Students' speech was recorded and then transcribed. The time was limited up to 12 minutes. The researcher controlled the time for students' responses. The study applies analysis of fourteen categories according to the flowing two criteria, notably considering the content/meaning of students' responses and type of solution. The results of students' responses analysis according to their content are illustrated in Table 1.

Table 1

Analysis of students' responses according to their content

\begin{tabular}{llll}
\hline Types of solution & \multicolumn{2}{l}{ Types of solution } \\
\hline Category & Content & Category & Content \\
\hline Text & $\begin{array}{l}\text { Repeating information } \\
\text { from the task during } \\
\text { reading the text }\end{array}$ & Solution & Implementing solution \\
Images & $\begin{array}{l}\text { Generating possible } \\
\text { solutions }\end{array}$ & Operation & $\begin{array}{l}\text { Verbal expressing of } \\
\text { separate actions }\end{array}$ \\
Intentions & $\begin{array}{l}\text { Evaluating ideas and Schema } \\
\text { choosing one possible } \\
\text { Models }\end{array}$ & $\begin{array}{l}\text { Verbal expressions of } \\
\text { the consequence of } \\
\text { actions }\end{array}$ \\
& $\begin{array}{l}\text { Evaluate the best Tools } \\
\text { solutions in the } \\
\text { current academic } \\
\text { setting }\end{array}$ & $\begin{array}{l}\text { Considering } \\
\text { limitations } \\
\text { exploring } \\
\text { relationship between } \\
\text { concepts }\end{array}$ \\
\hline
\end{tabular}

The results of students' responses analysis according to their content are illustrated in Table 2.

Table 2

Analysis of students' responses according to their meaning

\begin{tabular}{|c|c|c|c|}
\hline \multicolumn{2}{|c|}{ Types of solution } & \multicolumn{2}{|l|}{ Types of solution } \\
\hline Category & Meaning & Category & Meaning \\
\hline Attitude & $\begin{array}{l}\text { Differentiate } \\
\text { from opinion }\end{array}$ & Argumentation & $\begin{array}{l}\text { Give evidence-based } \\
\text { argumentation for } \\
\text { ways of solution }\end{array}$ \\
\hline Specifying & $\begin{array}{l}\text { Stating the } \\
\text { specifically }\end{array}$ & Evaluation & $\begin{array}{l}\text { Evaluate alternative } \\
\text { ways of solution }\end{array}$ \\
\hline Assumptions & 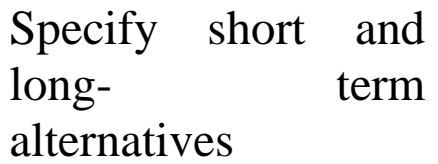 & Implementation & $\begin{array}{l}\text { Evaluate long-term } \\
\text { results based on final } \\
\text { solution }\end{array}$ \\
\hline
\end{tabular}


Participants. A total sample of 91 participants from Kherson State University was recruited through the Students' Union, 33 first-year students, 33 second-year students, and 25 fourth-year students. The inclusion criteria for participants were to be over 18 years old and to be currently a student of Kherson State University. The mean age of the participants was 21,5 $\pm 2,7$.

\section{Results and Discussion}

The descriptive statistics of speech production is presented in Table 3.

Table 3

Descriptive statistics of speech production during academic task solving

\begin{tabular}{llllll}
\hline \multirow{2}{*}{$\begin{array}{l}\text { Category } \\
\text { content }\end{array}$} & \multicolumn{2}{l}{$\begin{array}{l}\text { Descriptive } \\
\text { statistics }\end{array}$} & \multirow{2}{*}{$\begin{array}{l}\text { Category } \\
\text { meaning }\end{array}$} & \multicolumn{2}{l}{ Statistics } \\
\cline { 2 - 3 } \cline { 5 - 6 } & Mean & SD & & Mean & SD \\
\hline Text & 57.70 & 12.69 & Attitudes & 13.36 & 8.15 \\
Images & 8.32 & 6.26 & Specifying & 11.89 & 7.72 \\
Intentions & 2.16 & 2.16 & Assumptions & 16.51 & 10.22 \\
Models & 3.26 & 3.29 & Argumentation & 27.00 & 14.75 \\
Solution & 15.05 & 8.54 & Evaluation & 15.05 & 10.30 \\
Operations & 11.17 & 8.93 & Implementation & 16.18 & 8.61 \\
Schema & 0.95 & 2.91 & & & \\
Tools & 1.39 & 2.67 & & & \\
\hline
\end{tabular}

It is apparent from this table that text is the the most expressed category according to the content. Considering that meaning of the category text is repeating information from the task, we can infer that repeating and reproducing information from the task is an important phase in the academic task solving. The frequency of the category text $(57.7 \pm 12.69)$ is much higher than categories of solution (15.05 \pm 8.54$)$ and operations (11.17 \pm 8.93 ), respectively $\varphi^{*}=6.18$ and $\varphi^{*}=6.96$; $\mathrm{p}<.001$. Closer inspection of the table also shows that categories of solution $(15.05 \pm 8.54)$ and operations $(11.17 \pm 8.93)$ are much higher than categories of schema (0.95 \pm 2.91$)$, tools (1.39 \pm 2.67$)$, intentions $(2.16 \pm 0.95)$, and models (2.16 \pm 2.16$)$. Interestingly, the fast solution without deep analysis and evaluation of tools and models was observed in academic activity in students.

The findings show that that the high frequency of the category operations (11.17 \pm 8.93$)$ is observed. It means that verbal expression of students' operations is more preferable for students than planning, modeling and analyzing existing tools. These findings corroborate with previous research indicating students' verbal activity in the self-regulation of the cognitive processing (Savchenko, 2016). The results show that category of images $(8.32 \pm 6.26)$ is more frequent than categories of schema (0.95 \pm 2.91$)$, tools (1.39 \pm 2.67$)$, and intentions (2.16 \pm 0.95$)$, respectively $\left(\varphi^{*}=2.56 ; \varphi^{*}=2.31 ; p<.01\right.$ and $\varphi^{*}=1.9 ; p=.03$. The category of images indicates the students' tendency to define the primary direction in evaluating alternative ways for 
the academic task solution. However, this tendency restricts searching for alternative ways of solution and develops the readiness for making decision. What stands out in the table is that the categories according to the meaning were equally distributed in the students speech. The category of argumentation has a higher frequency $(27 \pm 14.75)$ comparatively with other categories (27 \pm 14.75$)$. This frequency of this category is much higher than frequency of the categories specifying (11.89 \pm 7.72$)$, evaluation $(15.05 \pm 10.30)$, implementation (16.18 \pm 8.61$)$, and assumption (16.51 \pm 10.22$)$. This result may be explained by the fact that giving evidence-based argumentation for ways of solutions is aligned with the efficient strategy for solution and making decision.

Table 4 illustrates the relationship between speech activity and academic task solving.

Table 4

Correlation between speech activity and efficient academic task solving in students

\begin{tabular}{llllll}
\hline Category & \multicolumn{2}{l}{ Correlation } & Category & \multicolumn{2}{c}{ Correlation } \\
\cline { 2 - 3 } content & $\mathrm{r}$ & $\mathrm{p}$ & meaning & $\mathrm{r}$ & $\mathrm{p}$ \\
\hline Text & -.12 & .256 & Attitudes & -.25 & $.02^{*}$ \\
Images & -.48 & .66 & Specifying & .15 & .15 \\
Intentions & -.14 & .89 & Assumptions & -.11 & .31 \\
Models & .23 & $.03^{*}$ & Argumentation & .24 & $.03^{*}$ \\
Solutions & .20 & .06 & Evaluation & -.31 & $.003^{*}$ \\
Operations & -.11 & .92 & Implementation & .29 & $.006^{*}$ \\
Schema & $-0,08$ & 0,481 & & & \\
Tools & $-0,18$ & 0,1 & & & \\
\hline Note. ${ }^{*} \mathrm{p}<.05,{ }^{* *} \mathrm{p}<.01$ & & & &
\end{tabular}

Closer inspection of the table shows that no correlation was found between frequency of the category text and efficient academic task solving $(\mathrm{r}=-.12, \mathrm{p}<.01)$. A possible explanation for this might be that repeating the information from the task may not be a robust predictor of efficient academic task solving, since repeating may indicate the automatic reproducing information without deep understanding.

A positive correlation was found between category of models and efficient academic task solving $(\mathrm{r}=.23 ; \mathrm{p}<.05)$, therefore, evaluating the best solutions in the current academic setting is a positive predictor of an efficient final solution. Evidence consistently suggests that efficient academic task solving is more aligned with meaning categories than content categories. Particularly, the level of efficiency is more high in students with frequent categories of argumentation $(\mathrm{r}=.24 ; \mathrm{p}<.05)$ and implementation $(\mathrm{r}=.29 ; \mathrm{p}<.01)$ than with categories of attitudes $(\mathrm{r}=-.25 ; \mathrm{p}<.05)$ and evaluation $(\mathrm{r}=-.31 ; \mathrm{p}<.01)$.. 
Argumentation in different phases of the academic task solving has a positive impact on efficient solution, since it is aligned with deep understanding of the academic task content.

Moreover, argumentation facilitates capturing relationship between different parts of the task, and specify short and long- term alternatives. One unanticipated finding was that there is a negative correlation between attitudes and academic task solving, since the negative attitudes related with previous experience might have a poor impact on the solution of the task. Another possible explanation might be that a negative attitude is aligned with much cognitive efforts, which has a poor impact on final results. The argumentation aligned with a personal experience might be also a negative predictor of academic task solving since it activates the deep levels of reflection.

Therefore, evidence consistently suggests that argumentation, modeling, implementation, absence of attitudes are robust predictors of the efficient academic task solving.

The relationship between styles of reflection and students`speech was explored by One-Way ANOVA and Two-Way ANOVA, Statistica 17.00.

The results indicate that reflective style is not related with students speech in terms of content category $(\mathrm{F}=.64)$ and meaning category $(\mathrm{F}=.51)$. The results also show that the most developed style in students is sequential style. Furthermore, sequential style is related to meaning category $(\mathrm{F}=2.0 ; \mathrm{p}<.02)$.

Table 5 illustrates the results of Two-Way ANOVA.

Table 5

Relationship between students' information processing style and speech production during academic task solving

\begin{tabular}{|c|c|c|c|c|}
\hline \multirow{2}{*}{$\begin{array}{c}\text { Information processing } \\
\text { style }\end{array}$} & $\mathrm{F}$ & $\mathrm{p}$ & $\mathrm{F}$ & $\mathrm{p}$ \\
\hline & \multicolumn{2}{|c|}{ Content categories } & \multicolumn{2}{|c|}{ Meaningful categories } \\
\hline \multicolumn{5}{|c|}{ Reflective and sequential information processing style } \\
\hline Reflective & 1,19 & 0,29 & 0,28 & 0,99 \\
\hline Sequential & 3,07 & 0,0003 & 0,55 & 0,85 \\
\hline Reflective / Sequential & 1,61 & 0,03 & 0,57 & 0,93 \\
\hline \multicolumn{5}{|c|}{ Reflective and sequential information processing style } \\
\hline Reflective & 1,98 & 0,02 & 0,35 & 0,96 \\
\hline Verbal & 2,17 & 0,01 & 0,48 & 0,89 \\
\hline Reflective /Verbal & 2,35 & 0,0003 & 0,89 & 0,60 \\
\hline
\end{tabular}

What stands out in the table is the relationship between information processing style and content categories. Moreover, the developed reflective style might be an important condition for other styles, notably sequential and verbal. Table 6 illustrates the relationship between students`information processing style and content categories. 
Table 6

Students' information processing style and content categories

\begin{tabular}{lcccc}
\hline \multicolumn{1}{c}{ Content categories } & $\mathrm{F}$ & $\mathrm{p}$ & $\mathrm{F}$ & $\mathrm{p}$ \\
\cline { 2 - 5 } & \multicolumn{2}{c}{ Reflective } & S Sequential & \multicolumn{2}{c}{ Reflective / Verbal } \\
\hline Text & 2,05 & 0,09 & 2,54 & 0,05 \\
Intentions & 0,76 & 0,56 & 2,63 & 0,04 \\
Models & 0,14 & 0,96 & 2,67 & 0,04 \\
Tools & 6,34 & 0,000 & 6,79 & 0,000 \\
\hline
\end{tabular}

Evidence consistently suggests that students with a high level of reflective та sequential styles, often apply category tools. It means that they consider limitations and explore the relationship between concepts during academic task solving.

Students with a high level of reflective and verbal style less frequently apply category text (34.55 \pm 12.39$)$, comparatively with students with a low level of reflective ra verbal style (65.94 \pm 4.13$)$. Students with a high level of reflective and verbal style more frequently apply category tools $(6.61 \pm 1.96)$ and less frequently category intentions $(1.69 \pm 1.78)$, comparatively with students with a low level of

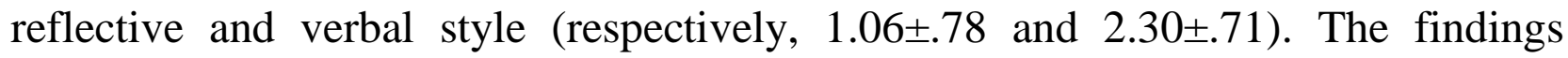
indicate that category models is more frequent in students with a medium level of reflective style (3.61 \pm .99$)$, comparatively with students with a high (2.05 \pm 2.76$)$. and a low (2.69 \pm 1.01$)$ level. It is in line with the idea of optimal representation of different reflective elements in an efficient individual cognitive activity (Karpov, 2004). Speech production in categories of models evaluates the best solutions in the current academic setting providing an efficient academic task solving.

\section{Conclusion}

Reflective syle of information processing might not be an independent factor, effecting content and meaningful categories in students speech. However, information processing reflective style has an effect on verbal and sequential styles, which are the robust predictors of speech production. Therefore, this study set out to capture the relationship between students `reflective information processing style and speech production during academic tasks solving. The research has shown that reflective style is an important inner condition for other information processing styles, which have a positive effect on speech production. The findings of this study suggest that content categories of models and tools are closely aligned with an efficient academic task solving. Therefore, evaluating the best solutions in the current academic setting, considering limitations, and exploring the relationship between concepts have a strong effect on positive outcome of academic task solving. The study should be repeated using experimental conditions and capturing cause-effect of information processing style on task solving in the academic settings. 


\section{References}

Боса, В. П. Мовленнєва компетентність майбутніх учителів іноземних мов: методологія проблеми. Восточный Европейский научный журнал: международный польский научный журнал. 2017, 11(27), Ч. 3, 8-13.

Залевская А. А. «Рефлексия» и «языковое сознание»: вопросы терминологии. Вестник Тверского государственного университета. Серия «Филология». 2015, 4, 29-36.

Карпов А. В. Психология рефлексивных механизмов деятельности. М. : Изд-во «Институт психологии РАН», 2004.

Кулик О. Поняття рефлексії, її сутність та роль у методиці навчання української мови. Українська мова і література в школі. 2014. № 3. С. 2-7.

Найдьонов М. І. Формування системи рефлексивного управління в організаціях. К.: Міленіум, 2008.

Рубинштейн С. Л. Бытие и сознание. Человек и мир. СПб.: Питер, 2003.

Савченко О. В. Рефлексивна компетентність особистості. Херсон : ПП Вишемирський В. С., 2016.

Савченко О. В. Стиль розв’язання проблемно-конфліктної ситуації як аспект аналізу життєвого шляху особистості. Вісник Одеського національного університету. Серія : Психологія. 2015, Т. 20, 2 (36), Ч. 1, 142-152.

Семенов И. Н., Степанов С. Ю. Рефлексия в организации творческого мышления и саморазвития личности. Вопросы психологии. 1983, № 2, 35-42.

Старовойтенко Е. Б. Культурная психология личности. М.: Академический проспект : Гаудемус, 2007.

Холодная М. А. Когнитивные стили. О природе индивидуального ума. СПб. : Питер, 2004.

Шаров А. С. Онтология психологических механизмов рефлексии. Вестник Омского государственного педагогического университета : электрон. науч. журнал. 2006. URL: http://sfrik.omskreg.ru/res.

Щедровицкий Г. П. Процессы и структуры в мышлении: курс лекций. Из архива Г. П. Щедровицкого. Т. 6. М. : «Путь», 2003.

Felder R.M. \& Solomon B.A. Index of learning styles questionnaire. North Carolina State University, 2001. Retrieved from http://www2.ncsu.edu/unity/lockers/users/f/felder/ public/ILSdir/ILS-a.html.

Kagan, J. (1965). Reflection-impulsivity: the generality and dynamics of conceptual tempo. Journal of Abnormal Psychology, 77, 17-24.

Vygranka, T. (2019). The features of formation of speech competence of future philologists in the educational process of institution of higher education. International Academy Journal Web of Scholar. 5(35), 26-30. https://doi.org/10.31435/rsglobal_wos/31052019/6502

\section{References (translated and transliterated)}

Bosa, V. P. (2017). Movlennieva kompetentnist maybutnikh uchyteliv inozemnykh mov: metodolohiya problemy. Vostochnyi Yevropeiskiy Nauchnyi Zhurnal: Mezhdunarodnyi Polskiy Nauchnyi Zhurnal, 11(27), 3, 8-13.

Zalevskaya, A. A. (2015). "Refleksiya” i "yazykovoe soznanie”: voprosy terminologii ["Reflection" and "linguistic consciousness": issues of terminology]. Vestnik Tverskogo Gosudarstvennogo Universiteta. Seriya "Filologiya”, 4, 29-36.

Karpov, A. V. (2004). Psihologiya Refleksivnyh Mehanizmov Deyatelnosti [Psychology of reflective mechanisms of activity]. Moscow: Institute of Psychology of the Russian Academy of Sciences.

Kulyk, O. (2014). Poniattia refleksiyi, yii sutnist ta rol u metodytsi navchannia ukrayinskoyi movy [The concept of reflection, its essence and role in the methodology of teaching the Ukrainian language]. Ukrayinska Mova i Literatura v Shkoli, 3, 2-7. 
Naydonov, M. I. (2008). Formuvannia Systemy Refleksyvnoho Upravlinnia v Orhanizatsiyakh [Formation of Reflexive Management System in Organizations]. Kyiv: Milenium.

Rubinshtejn, S. L. (2003) Bytie i Soznanie. Chelovek i Mir [Genesis and Consciousness. Human and the World.]. S.-Petersburg: Piter.

Savchenko, O. V. (2016). Refleksyvna Kompetentnist Osobystosti [Personality`s Reflective Competence]. Kherson: Vyshemyrskyi.

Savchenko, O. V. (2015) Styl rozvyazannia problemno-konfliktnoyi sytuatsiyi yak aspekt analizu zhyttievoho shliakhu osobystosti [Style of resolving a problem-conflict situation as an aspect of person's life experience analysis]. Visnyk Odeskoho natsionalnoho universytetu. Seriya: Psykholohiya, Vol. 20, 2(36), 1, 142-152.

Semenov I. N. \& Stepanov S. Yu.(1983) Refleksiya v organizatsii tvorcheskogo myishleniya i samorazvitiya lichnosti [Reflection in the organization of creative thinking and personal self-development]. Voprosy Psihologii, 2, 35-42.

Starovoitenko, E. B. (2007). Kulturnaya Psihologiya Lichnosti [Cultural Psychology of the Person]. Moscow: Akademicheskiy Prospekt: Gaudemus, 2007.

Kholodnaya, M. A. (2004). Kognitivnye Stili. O Prirode Individualnogo Uma [Cognitive Styles. On the Nature of the Individual Mind]. S.-Petersburg: Piter.

Sharov A. S. (2006) Ontologiya psihologicheskih mehanizmov refleksii [Ontology of psychological mechanisms of reflection]. Vestnik Omskogo Gosudarstvennogo Pedagogicheskogo Universiteta. Retrieved from http://sfrik.omskreg.ru/res.

Schedrovitskiy G. P. (2003) Protsessyi i strukturyi v myishlenii: kurs lektsiy [Processes and structures in thinking: a course of lectures.]. Iz arhiva G. P. Schedrovitskogo. Vol. 6. Moscow: Put.

Felder, R.M. \& Solomon, B.A. (2001). Index of learning styles questionnaire. North Carolina State University. Retrieved from http://www2.ncsu.edu/unity/lockers/users/f/felder/public/ILSdir/ ILS-a.html.

Kagan, J. (1965). Reflection-impulsivity: the generality and dynamics of conceptual tempo. Journal of Abnormal Psychology, 77, 17-24.

Vygranka, T. (2019) The Features of Formation of Speech Competence of Future Philologists in The Educational Process of Institution of Higher Education. International Academy Journal Web of Scholar, 5(35), 26-30. https://doi.org/10.31435/rsglobal_wos/31052019/6502 